\title{
MiXING BISMARCK AND CHILD PENSION SYSTEMS: AN OPTIMUM TAXATION APPROACH
}

\author{
ROBERT FENGE \\ JAKOB VON WEIZSÄCKER
}

CESIFO WORKING PAPER NO. 1751

CATEgory 1: Public FinANCE

JUNE 2006

An electronic version of the paper may be downloaded

- from the SSRN website:

- from the RePEc website:

wWw.SSRN.com

- from the CESifo website:

www.RePEc.org

www.CESifo-group.de 


\title{
MiXING BISMARCK AND CHILD PENSION SYSTEMS: AN OPTIMUM TAXATION APPROACH
}

\begin{abstract}
The labor-leisure distortion of a pay-as-you-go pension system can be reduced through a stronger tax-benefit link or Bismarck pension system. Distortions of the fertility decision can be reduced through the introduction of a stronger child-benefit or child pension system. Within our optimal taxation framework, we find a Corlett-Hague result regarding the optimal mix of the two: if and only if children are more complementary to leisure should the taxbenefit link be given a positive weight at the expense of the child-benefit link. The model also allows us to examine the infertility insurance argument that may justify redistribution from families with children to those without implied by most pension systems. We find that the opposite redistribution, from the childless to those with children, would be efficient if individuals have low risk aversion. Redistribution in favor of the infertile would only be justified when risk aversion is high.
\end{abstract}

JEL Code: H23, H55, J13, J18.

Keywords: pay-as-you-go pension, fertility, externality, Bismarck pension, optimal taxation.

Robert Fenge

Ifo Institute for Economic Research at the University of Munich

Poschingerstr. 5

81679 Munich

Germany

fenge@ifo.de
Jakob von Weizsäcker

Bruegel

Rue de la Charité 33

1210 Brussels

Belgium

jvw@bruegel.org

9th June 2006

We are grateful for helpful suggestions and comments of Friedrich Breyer, Hans-Werner Sinn and participants of the CESifo Group Seminar on 28th November 2005. 


\section{Introduction}

This article focuses on two important distortions that pay-as-you-go (PAYG) pension systems may cause: (i) a labor-leisure distortion, and (ii) a fertility distortion.

The labor-leisure distortion is caused by the implicit tax that PAYG pension schemes levy on wage income because average returns to PAYG contributions are typically lower than investing the same amount in the capital market. This is due to the implicit debt of the PAYG pension system that is accumulated during its introduction. In addition, the returns to marginal pension contributions may be further depressed as the result of a weak tax benefit link. It has been shown that a move from Beveridgean pension (no tax-benefit link) to Bismarckian pension (full tax-benefit link) reduces the implicit tax and, hence, the laborleisure distortion while a move from a Bismarckian to a fully funded pension system does not succeed in reducing the labor-leisure distortion further for all generations (Fenge 1995; Brunner, 1996, Sinn, 2000).

But PAYG pension systems in principle also distort the fertility decision. Through the PAYG pension the whole parent generation benefits from earnings of each member of the next generation. If the benefits of children are thereby socialized while the cost of children remain private, the implied positive fiscal externality of having children would tend to distort fertility to a sub-optimal level. However, by linking the individual number of children and benefits in the pension formula, the fertility distortion can be eliminated as Kolmar (1997) and von Auer and Buettner (2005) have shown in a model with elastic fertility supply and inelastic labor supply.

This raises the question what efficient PAYG pension systems look like when both labor supply and fertility are endogenous. Our present paper addresses this question within the modeling framework developed by Fenge and Meier (2004, 2005): the pension fund is divided into a contribution-related Bismarckian pension and a fertility-related child pension component. By increasing the weight of the Bismarck pension, the labor-leisure distortion can be reduced, and by increasing the share of the child pension with a strong child-benefit link (more precisely a strong positive link between one's number of children and one's pension benefits), the fertility distortion can be reduced. However, at the possibility frontier, a stronger contribution-benefit link implies a weaker child-benefit link and vice versa.

The paper commences by developing a simple model that captures this trade-off. Interestingly, our model immediately yields the insight that the policy optimization problem at any time $t$ is equivalent to the classic Corlett-Hague (1957) problem from optimal tax theory where consumption and children are two consumption goods that can be taxed while leisure cannot be taxed. Hence, it is found that a pure child pension system is efficient when consumption and children are equally complementary to leisure. When children are more complementary to leisure than consumption, a more Bismarckian pension system is efficient. And when consumption is more complementary to leisure than children, then a hyper-child pension system is efficient where children are subsidized at the expense of consumption. If, as seems plausible, children are indeed more complementary to leisure 
than consumption, this may help to rationalize the historical emphasis on the child-benefit link.

Since the representative agent framework does not capture distributional objectives, a model with two productivity types is also discussed, relying on the papers by Edwards et al (1994) and Nava et al (1995) for the equivalent optimal taxation problem. Again, albeit for different reasons, the Bismarck pension component should be positive if children are more complementary to leisure than consumption.

The significance of these results is further reinforced as we shown that the child pension discussed above is equivalent to child benefits and tax deductibility of child expenditure. Hence, these instruments are interchangeable within the present modeling framework, and the often controversial claims that one of these instruments should be favored over another would need to rely on additional assumptions.

Finally, we extend the representative agent model by examining the optimal response to an ex ante infertility risk. Using a simple separability assumption, we find that the direction of the optimum ex-post transfer between fertile and infertile depends on the degree of the central planners aversion towards inequality . For a neutral attitude, we find that the optimal ex-post redistribution consists of a net fiscal transfer from those who remain childless to those with children, despite the fact that the fertile already enjoy higher utility overall. The reason for this is that children reduce private consumption compared to the infertile, and, as a result, those with children have a higher marginal utility of funds than those without children. Only when the degree of inequality aversion is high, would an ex-post transfer from the fertile to the infertile be efficient.

These findings contrast with the result of Sinn (2004) who finds that some positive insurance against childlessness is always desirable. The underlying reason for these different results is that Sinn treats children as investment goods with negative expected financial cost, a highly relevant assumption within a historical or developing country context, while we treat children as consumption goods with a positive financial cost as might be more appropriate for today's OECD countries.

\section{The Model}

A standard overlapping generations model forms the basis of our considerations. Each generation $t$ works and reproduces during period $t$ and lives in retirement during period $t+1$. The lifetime utility of generation $t$ depends on lifetime consumption in net present value terms $c_{t}$, the number of children $k_{t}$, and leisure written as total available time normalized to 1 minus the time worked $L_{t}$.

The representative agent of generation $t$ contributes to the pay-as-you go pension system at contribution rate $\tau_{t}$, contributing a total of $w_{t} L_{t} \tau_{t}$ where $w_{t}$ denotes the uniform wage rate of generation $t$. The net present value of the average pension of the same representative agent is given by 
$\bar{k}_{t} \frac{\tau_{t+1} w_{t+1} \bar{L}_{t+1}}{R_{t+1}}$

which is the average number of children of the members of generation $t$, multiplied by the pension contributions of each member of the next generation $t+1$, discounted by the relevant interest factor $R_{t+1}$. A share $(1-\alpha)$ of this pension is paid out as a Bismarck pension where benefits are determined by individual contributions compared to the generation average, and a child pension where benefits are determined by the number of children raised compared to the generation average. The total pay-as-you go pension of the representative agent can thus be written as

$$
\left[(1-\alpha) \frac{w_{t} L_{t} \tau_{t}}{w_{t} \bar{L}_{t} \tau_{t}}+\alpha \frac{k_{t}}{\bar{k}_{t}}\right] \bar{k}_{t} \frac{\tau_{t+1} w_{t+1} \bar{L}_{t+1}}{R_{t+1}}=\left[(1-\alpha) L_{t} \frac{\bar{k}_{t}}{\bar{L}_{t}}+\alpha k_{t}\right] \frac{\tau_{t+1} w_{t+1} \bar{L}_{t+1}}{R_{t+1}}
$$

Consequently, the individual maximization problem of the representative agent of generation $t$ reduces to:

$$
\max _{c_{t}, k_{t}, 1-L_{t}} U\left(c_{t}, k_{t}, 1-L_{t}\right)
$$

s.t. $w_{t} L_{t}\left(1-\tau_{t}\right)+\left[\left(1-\alpha_{t}\right) L_{t} \frac{\bar{k}_{t}}{\bar{L}_{t}}+\alpha_{t} k_{t}\right] \frac{\tau_{t+1} w_{t+1} \bar{L}_{t+1}}{R_{t+1}}=c_{t}+B_{t} k_{t}$

where $B_{t}$ is the direct cost per child. For simplicity, it is assumed that the child cost is proportional to the number of children and that each child only has only one parent. For convenience, it is also assumed that the number of children $k_{t}$ is continuous. One interpretation of this assumption is that $k_{t}$ stands for the number of children measured in quality units. In addition, it is assumed that the direct cost per child $B_{t}$ is greater than the average pension payment per child $\tau_{t+1} w_{t+1} \bar{L}_{t+1} / R_{t+1}$. This assures that children are a consumption good with a positive net cost.

From the government's perspective, a pension policy can be described as sequence of policy pairs $\left\{\left(\alpha_{0}, \tau_{0}\right),\left(\alpha_{1}, \tau_{1}\right),\left(\alpha_{2}, \tau_{2}\right), \ldots\right\}$. The obvious question to ask for any given policy is whether it is efficient. The traditional Pareto criterion only allows comparisons between states with the same individuals and therefore, a fortiori, also the same number of individuals. However, the policy parameters in our model generally impact fertility and thereby the size of the next generation.

Therefore, a modified efficiency criterion is used: a pension policy is said to be efficient if no policy reform exists that makes at least one representative agent of the presently living or future generations better off while not making any representative agent of any other generation worse off. This efficiency criterion is in fact equivalent to the Pareto criterion if 
it is assumed that for any generation those who remain unborn in a particular realization of the world have exactly the same level of utility as the representative agent of the members of the generation who are actually born.

From a political perspective, our efficiency criterion appears reasonable. In effect, the Pareto criterion is applied to everybody who is at present an actor in the political economy sense by virtue of being alive. Already deceased generations are protected through the irreversibility of the past. And while potential members of future generations are not completely protected since they have no guarantee of being born, they are at least to some extent protected through the restriction that their representative agent is not to be made worse off. Nevertheless, solutions that are efficient in the above sense but imply a rapid demographic implosion or explosion should be interpreted with some caution.

As a next step we define global and local efficiency of a pension policy.

Definition 1: A pension policy $\left\{\left(\alpha_{0}, \tau_{0}\right),\left(\alpha_{1}, \tau_{1}\right),\left(\alpha_{2}, \tau_{2}\right), \ldots\right\}$ is called globally efficient if no globally reformed policy $\left\{\left(\tilde{\alpha}_{0}, \tilde{\tau}_{0}\right),\left(\tilde{\alpha}_{1}, \tilde{\tau}_{1}\right),\left(\tilde{\alpha}_{2}, \tilde{\tau}_{2}\right), \ldots\right\}$ exists that is more efficient.

Definition 2: And a pension policy $\left\{\left(\alpha_{0}, \tau_{0}\right),\left(\alpha_{1}, \tau_{1}\right),\left(\alpha_{2}, \tau_{2}\right), \ldots\right\}$ is called locally efficient if no local reform policy that only changes the pension parameters of a particular generation $\left\{\left(\alpha_{0}, \tau_{0}\right),\left(\alpha_{1}, \tau_{1}\right),\left(\alpha_{2}, \tau_{2}\right), \ldots,\left(\alpha_{t-1}, \tau_{t-1}\right),\left(\tilde{\alpha}_{t}, \tilde{\tau}_{t}\right),\left(\alpha_{t+1}, \tau_{t+1}\right), \ldots\right\}$ for any generation $t \geq 0$ exist that is more efficient than the original policy.

Clearly, a pension policy that is not locally efficient cannot be globally efficient. Hence, local efficiency is a necessary condition for global efficiency. However, local efficiency is not generally a sufficient condition for global efficiency. The essential reason for this is that local efficiency may be satisfied everywhere while the growth rate of the wage sum exceeds the interest rate for every generation - the so-called Aaron condition (Aaron, 1966). In other words, the locally efficient policy might be dynamically inefficient and therefore not globally efficient since the expansion of the pay-as-you-go pension system would lead to an efficiency gain. However, the validity of the Aaron condition would be inconsistent with the small open economy assumption in the long run, provided that the rest of the world is to the left of the golden rule. Since the relevant issues are examined by Kolmar (1997), we focus on local efficiency in this paper.

In order to test for local efficiency at time $t$, we examine the following maximization problem for the state: Vary the policy parameters $\left(\alpha_{t}, \tau_{t}\right)$ so as to maximize the utility of the representative agent of generation $t$ while keeping the representative agents of all other generations indifferent compared to the status quo. Luckily, the policy parameters $\left(\alpha_{t}, \tau_{t}\right)$ only affect the utility of the representative agents of generation $t$ and that of generation $t-1$. In fact, the utility of generation $t-1$ is only affected through the channel of the total pension contributions of generation $t$. Therefore, in order to keep the utility of all other generations constant, it suffices to introduce the additional constraint that the pension contributions of generation $t$ must not vary as the policy parameters of time $t$ are changed. Or more formally 
$\left.\left(L_{t} w_{t} \tau_{t}\right)\right|_{\left(\alpha_{t}, \tau_{t}\right)}=\left(\tilde{L}_{t} w_{t} \tilde{\tau}_{t}\right)_{\left(\tilde{\alpha}_{t}, \tilde{\tau}_{t}\right)}$

And since we make the small open economy assumption that $\left\{\left(w_{0}, R_{0}\right),\left(w_{1}, R_{1}\right),\left(w_{2}, R_{2}\right), \ldots\right\}$ are given, this reduces further to

$$
\left.\left(L_{t} \tau_{t}\right)\right|_{\left(\alpha_{t}, \tau_{t}\right)}=\left(\tilde{L}_{t} \tilde{\tau}_{t}\right)_{\left(\tilde{\alpha}_{t}, \tilde{\tau}_{t}\right)}
$$

Consequently, the local maximization problem of the government can be written as

$$
\begin{aligned}
& \max _{\alpha_{t}, \tau_{t}}\left[\begin{array}{l}
\max _{c_{t}, k_{t}, 1-L_{t}} U\left(c_{t}, k_{t}, 1-L_{t}\right) \\
\text { s.t. } \left.L_{t} w_{t}\left[\left(1-\tau_{t}\right)+\left(1-\alpha_{t}\right) \frac{\bar{k}_{t}}{w_{t} \bar{L}_{t}} x\right]=c_{t}+k_{t}\left(B_{t}-\alpha x\right)\right]
\end{array}\right] \\
& \text { s.t. }\left.\left(L_{t} \tau_{t}\right)\right|_{\left(\alpha_{t}, \tau_{t}\right)}=\left(\tilde{L}_{t} \tilde{\tau}_{t}\right)_{\left(\tilde{\alpha}_{t}, \tilde{\tau}_{t}\right)}
\end{aligned}
$$

where $\mathrm{x}$ denotes the pension contribution of the representative agent of the $t+1$ generation: $x=\tau_{t+1} w_{t+1} \bar{L}_{t+1} / R_{t+1}$.

\section{Equivalence Results from Optimum Taxation Theory}

It turns out that this local maximization problem of the government can be equivalently rewritten in terms of the classic optimal tax problem of Corlett-Hague (1957) where the state optimizes the relative tax on two consumption goods subject to the constraint that a total revenue of $\rho_{t}$ needs to be raised and that leisure cannot be taxed. We demonstrate this equivalence result by defining new terms for the optimization problem as follows:

$$
\begin{aligned}
t_{c_{t}} & =\frac{1}{1-\tau_{t}+\left(1-\alpha_{t}\right) \frac{\bar{k}_{t}}{w_{t} \bar{L}_{t}} x}-1 \\
t_{k_{t}} & =\frac{1}{1-\tau_{t}+\left(1-\alpha_{t}\right) \frac{\bar{k}_{t}}{w_{t} \bar{L}_{t}} x} \frac{B_{t}-\alpha_{t} x}{B_{t}-x}-1 \\
\rho_{t} & =\left.\left(L_{t} \tau_{t}\right)\right|_{\left(\alpha_{t}, \tau_{t}\right)}
\end{aligned}
$$

By inserting these new terms, we obtain the formal equivalence to the Corlett-Hague optimization problem. 
$\max _{t_{c_{t}}, t_{k_{t}}}\left[\begin{array}{l}\max _{c_{t}, k_{t}, 1-L_{t}} U\left(c_{t}, k_{t}, 1-L_{t}\right) \\ \text { s.t. } L_{t} w_{t}=c_{t}\left(1+t_{c_{t}}\right)+k_{t}\left(B_{t}-x\right)\left(1+t_{k_{t}}\right)\end{array}\right]$
s.t. $R_{0}=\left(c_{t} t_{c_{t}}+k_{t}\left(B_{t}-x\right) t_{k_{t}}\right)$

\section{Proposition 1a:}

a) If children are as complementary to leisure as consumption, then a pure child pension system $\alpha_{t}=1$ is locally efficient.

b) If children are more complementary to leisure than consumption, then a child pension with weight smaller than one $\alpha_{t}<1$, complemented by a positive Bismarck pension system, is efficient.

c) If children are less complementary to leisure than consumption, then a child pension with greater weight than one $\alpha_{t}>1$, financed through a negative Bismarck pension system, is efficient.

Proof: Corlett-Hague (1957) have shown that

$\varepsilon_{k_{t},\left(1-L_{t}\right)}\left\{\begin{array}{l}> \\ = \\ <\end{array}\right\} \varepsilon_{c_{t},\left(1-L_{t}\right)} \Leftrightarrow t_{k_{t}}\left\{\begin{array}{l}> \\ = \\ <\end{array}\right\} t_{c_{t}}$.

From the definitions of $t_{k_{t}}, t_{c_{t}}$ it follows immediately that

$t_{k_{t}}\left\{\begin{array}{l}> \\ <\end{array}\right\} t_{c_{t}} \Leftrightarrow \alpha_{t}\left\{\begin{array}{l}< \\ = \\ >\end{array}\right\} 1$.

Hence

$\varepsilon_{k_{t},\left(1-L_{t}\right)}\left\{\begin{array}{l}> \\ = \\ <\end{array}\right\} \varepsilon_{c_{t},\left(1-L_{t}\right)} \Leftrightarrow \alpha_{t}\left\{\begin{array}{l}< \\ = \\ >\end{array}\right\} 1$

Q.E.D.

If the utility function is additively separable in all three arguments $U\left(c_{t}, k_{t}, 1-L_{t}\right)=u_{1}\left(c_{t}\right)+u_{2}\left(k_{t}\right)+u_{3}\left(1-L_{t}\right)$, then Proposition 1a can be reformulated as follows: 


\section{Proposition 1b:}

a) If the income elasticity of the number of children is equal to the income elasticity of consumption, then a pure child pension system $\alpha_{t}=1$ is locally efficient.

b) If the income elasticity of the number of children is children is greater than the income elasticity of consumption, then a child pension with weight smaller than one $\alpha_{t}<1$, complemented by a positive Bismarck pension system, is efficient.

c) If the income elasticity of the number of children is greater than the income elasticity of consumption, then a child pension with greater weight greater than one $\alpha_{t}>1$, financed through a negative Bismarck pension system, is efficient.

Proof: According to Goldman and Uzawa (1964), Theorem 4, the Slutsky terms of a strongly additively separable utility function can be written as

$$
S_{i j}(x)=\kappa(x)-\left(c_{t}, k_{t}, 1-L_{t}\right)=u_{1}\left(c_{t}\right)+u_{2}\left(k_{t}\right)+u_{3}\left(1-L_{t}\right)
$$

If there is additive separability of utility in all three arguments, this reduces to ${ }^{1}$

$$
S_{k,(1-L)}=\mu \frac{\partial k}{\partial M} \frac{\partial(1-L)}{\partial M}, S_{c,(1-L)}=\mu \frac{\partial c}{\partial M} \frac{\partial(1-L)}{\partial M}
$$

where $\mathrm{M}$ denotes the lump sum household income. Hence $\varepsilon_{k,(1-L)}>\varepsilon_{c,(1-L)}$ is equivalent to

$$
\frac{\partial k}{\partial M} \frac{M}{k}>\frac{\partial c}{\partial M} \frac{M}{c}
$$

This can be written as an inequality in income elasticities

$$
\eta_{k, M}>\eta_{c, M}
$$

\section{Q.E.D.}

It is unclear whether children or consumption are more complementary to leisure at the margin. However, in view of the high time demands of proper parenting compared to most other forms of consumption, we would not be surprised if children were indeed more complementary to leisure than other forms of consumption. In that case, the optimal solution would indeed involve a positive Bismarck pension as is presently observed.

Using the same strategy as before, the problem of the optimum pension mix can also be solved for agents with two productivity types $w_{t}^{\text {high }}>w_{t}^{\text {low }}$. By reformulating the problem in tax terms, we can again rely on classic result from the optimum taxation literature and summarized nicely in Boadway and Pestieau (2003), yielding:

\footnotetext{
${ }^{1}$ See for example Deaton and Muehlbauer (1980), page 138.
} 
Proposition 2a: If leisure is separable, a pure child pension system $\alpha_{t}=1$ is locally efficient.

Proof: Atkinson-Stiglitz (1976): Since leisure is assumed to be separable, distortions introduced by linear taxes into the consumption bundle of children and other consumption good would not be able to alleviate the incentive compatibility constraint between the two types. Hence $t_{k_{t}}=t_{c_{t}} \Leftrightarrow \alpha_{t}=1$.

Proposition 2b: If leisure is not separable, Proposition 1 holds.

Proof: See Edwards et al (1994) and Nava et al (1995) for the solution of the equivalent optimum taxation problem.

However, an important caveat needs to be applied to the latter two results. The assumption of linear commodity taxes is normally justified due to the possibility of private resale. This argument clearly cannot and should not be applied to the "consumption good" children. The government, for good reason, tracks the identity and number of children in each household. This opens up the possibility of non-linear elements in the taxation of children. In particular, it would generally be possible to further improve welfare through the introduction of a positive child license fee $f>0$ that would act as a non-distortionary lump sum tax.

\section{Adenauer Pension}

The first chancellor of the Federal Republic of Germany; Konrad Adenauer, claimed that the decision of having children were not subject to economic conditions: "Kinder bekommen die Leute immer" (transl.: "People have always children”). What implications does an inelastic supply of children have on a child-contingent pension? A first guess may be that the child factor should be reduced to zero. In the following we show that in fact a negative child factor will be optimal in order to reduce the implicit tax on labor incurred by a Bismarck pension.

If children are supplied inelastically at $\bar{k}_{t}$ then the individuals maximization problem reduces to:

$$
\begin{aligned}
& \max _{c_{t}, 1-L_{t}} U\left(c_{t}, 1-L_{t}\right) \\
& \text { s.t. } L_{t} w_{t}-L_{t} w_{t} \tau_{t}\left[1-\left(1-\alpha_{t}\right) \bar{k}_{t} \frac{\tau_{t+1} w_{t+1} \bar{L}_{t+1}}{\tau_{t} w_{t} \bar{L}_{t} R_{t+1}}\right]=c_{t}+\bar{k}_{t}\left(B_{t}-\alpha x\right)
\end{aligned}
$$

At $\alpha_{t}=0$ the implicit tax on labor due to the pay-as-you-go pension scheme remains positive if the payroll growth rate is smaller than the interest rate of the capital market, i.e. we are in a dynamic efficient equilibrium, and if contribution rates are not increased such that the loss in the return of the PAYG scheme is compensated (no Ponzi game): 


$$
\left.\left(\tau_{t}\left[1-\left(1-\alpha_{t}\right) \bar{k}_{t} \frac{\tau_{t+1} w_{t+1} \bar{L}_{t+1}}{\tau_{t} w_{t} \bar{L}_{t} R_{t+1}}\right]\right)\right|_{\alpha_{t}=0}>0 \text { iff } R_{t+1}>\bar{k}_{t} \frac{\tau_{t+1} w_{t+1} \bar{L}_{t+1}}{\tau_{t} w_{t} \bar{L}_{t}}
$$

The last assumption is reasonable because there is always an upper bound for contribution rates, e.g. by constitutional terms against expropriation.

Using again the formulation of an optimal tax problem for two commodity goods the following proposition can be stated

Proposition 3: If children are supplied inelastically, then an Adenauer Pension $\left(\alpha^{*}<0\right)$ is efficient.

Proof: If lump-sum taxation is possible then all distortionary taxes should be zero (see e.g. Sandmo, 1976; Auerbach, 1985). In our framework this means that the solution to the optimal tax problem:

$$
\begin{aligned}
& \max _{t_{c_{t}}, t_{k_{t}}}\left[\begin{array}{l}
\max _{c_{t}, 1-L_{t}} U\left(c_{t}, 1-L_{t}\right) \\
\text { s.t. } L_{t} w_{t}=c_{t}\left(1+t_{c_{t}}\right)+\bar{k}_{t}\left(B_{t}-x\right)\left(1+t_{k_{t}}\right)
\end{array}\right] \\
& \text { s.t. } R_{0}=\left(c_{t} t_{c_{t}}+\bar{k}_{t}\left(B_{t}-x\right) t_{k_{t}}\right)
\end{aligned}
$$

is a zero tax on consumption: $t_{c_{t}}^{*}=0$ because the tax on children $t_{k_{t}}^{*}>0$ is, by assumption, a lump sum instrument. Inserting the definitions of the commodity taxes yields

$$
\alpha_{t}^{*}=1-\frac{\tau_{t} w_{t} \overline{L_{t}}}{\overline{k_{t}} x}<0 \quad \text { iff }\left.\left(1-\left(1-\alpha_{t}\right) \bar{k}_{t} \frac{x}{\tau_{t} w_{t} \bar{L}_{t}}\right)\right|_{\alpha_{t}=0}>0
$$

with $x=\tau_{t+1} w_{t+1} \bar{L}_{t+1} / R_{t+1}$. If the implicit tax on labor is positive at the point $\alpha_{t}=0$ then the optimal child factor is negative $\alpha^{*}{ }_{t}<0$.

Q.E.D.

If children are supplied inelastically, a child factor smaller than one is in fact a lump-sum tax on children. According to optimal tax theory this lump-sum tax should be increased up to the point at which the distortionary implicit tax on labor is reduced to zero. In this case the pension should be reduced by $\alpha^{*}$ for each child so that the reduction of pensions adds to the direct cost of having children.

By the same token, an inelastic supply of labor implies with endogenous fertility implies $t_{k_{t}}^{*}=0, t_{c_{t}}^{*}>0$ and therefore $\alpha^{*}{ }_{t}>1$. In other words, a hyper-child pension is efficient that places all tax burden on labor, reproducing the result of von Auer und Büttner (2005). 


\section{Various Instruments for Fertility Policy}

Child pensions are not the only instrument available to set incentives for fertility. Other financial incentives can be given by direct child benefits or by deducing part of the child rearing costs from the pension contributions. Especially the second instrument is interesting in order to advance child support within the pension system compared to child-contingent pensions. There are some reasons why families should be better off with an early financial support for children one of which are credit constraints of young families. In the framework here, however, all instruments turn out to be perfect substitutes so that there is no a priori reason to favor one of the instruments.

Adding child benefits and the partial deductibility of child rearing costs in the model modifies the budget constraint to

$$
w_{t} L_{t}\left(1-\tau_{t}\right)+\beta_{t} B_{t} k_{t} \tau_{t}+\gamma_{t} B_{t} k_{t}+\left[\left(1-\alpha_{t}\right) L_{t} \frac{\bar{k}_{t}}{\bar{L}_{t}}+\alpha_{t} k_{t}\right] \frac{\tau_{t+1} w_{t+1} \bar{L}_{t+1}}{R_{t+1}}=c_{t}+B_{t} k_{t}
$$

$\beta_{t}$ denotes the fraction of the child rearing costs that can be deduced from the contribution to the pension scheme. We require partial deductibility so that $\beta_{t} B_{t} k_{t}<w_{t} L_{t} \cdot \gamma_{t}$ denotes the fraction of the child costs that is granted to the parents as child benefit.

The first-order conditions of maximizing utility with respect to this budget constraint yield the following marginal rates of substitution.

$$
\begin{aligned}
& \frac{u_{2}^{\prime}}{u_{1}^{\prime}}=B_{t}\left(1-\beta_{t} \tau_{t}-\gamma_{t}\right)-\frac{\alpha_{t}}{R} w_{t+1} \bar{L}_{t+1} \tau_{t+1} \\
& \frac{u_{3}^{\prime}}{u_{1}^{\prime}}=w_{t}\left(1-\tau_{t}\right)+\frac{\left(1-\alpha_{t}\right)}{R} \bar{k}_{t} w_{t+1} \frac{\bar{L}_{t+1}}{\bar{L}_{t}} \tau_{t+1}
\end{aligned}
$$

It suffices to show that any fertility instrument can be completely substituted by either of the two others in an economically equivalent way if the contribution rate $\tau$ is varied appropriately at the same time so that the pension of generation t- 1 does not suffer.

Proposition 4: All instruments for fertility policy are equivalent within the present model.

Proof: It suffices to show that the child pension can be substituted by either child benefits or deductibility of child rearing costs. Hence, we prove that a change of policy parameters $\left(\alpha_{t}, \beta_{t}, \tau_{t}\right) \rightarrow\left(0, \hat{\beta}_{t}, \hat{\tau}_{t}\right)$ or $\left(\alpha_{t}, \gamma_{t}, \tau_{t}\right) \rightarrow\left(0, \hat{\gamma}_{t}, \hat{\tau}_{t}\right)$ will not change first-order conditions.

Starting with the substitution of child pensions by deductibility of child rearing costs we have to prove that

$$
B_{t}\left(1-\beta_{t} \tau_{t}\right)-\frac{\alpha_{t}}{R} w_{t+1} \bar{L}_{t+1} \tau_{t+1}=B_{t}\left(1-\hat{\beta}_{t} \hat{\tau}_{t}\right)
$$




$$
\begin{aligned}
& w_{t}\left(1-\tau_{t}\right)+\frac{\left(1-\alpha_{t}\right)}{R} \bar{k}_{t} w_{t+1} \frac{\bar{L}_{t+1}}{\bar{L}_{t}} \tau_{t+1}=w_{t}\left(1-\hat{\tau}_{t}\right)+\frac{1}{R} \bar{k}_{t} w_{t+1} \frac{\bar{L}_{t+1}}{\bar{L}_{t}} \tau_{t+1} \\
& w_{t} L_{t}\left(1-\tau_{t}\right)+\beta_{t} B_{t} k_{t} \tau_{t}+\left[\left(1-\alpha_{t}\right) L_{t} \frac{\bar{k}_{t}}{\bar{L}_{t}}+\alpha_{t} k_{t}\right] \frac{\tau_{t+1} w_{t+1} \bar{L}_{t+1}}{R_{t+1}}-c_{t}-B_{t} k_{t} \\
& =w_{t} L_{t}\left(1-\hat{\tau}_{t}\right)+\hat{\beta}_{t} B_{t} k_{t} \tau_{t}+L_{t} \frac{\bar{k}_{t}}{\bar{L}_{t}} \frac{\tau_{t+1} w_{t+1} \bar{L}_{t+1}}{R_{t+1}}-c_{t}-B_{t} k_{t}
\end{aligned}
$$

Equation (15) implies

$$
\hat{\tau}_{t}=\tau_{t}+\frac{\alpha_{t}}{R} \bar{k}_{t} \frac{w_{t+1}}{w_{t}} \frac{\bar{L}_{t+1}}{\bar{L}_{t}} \tau_{t+1}
$$

Substituting for $\hat{\tau}_{t}$ in equation (14) yields

$$
\hat{\beta}_{t}=\frac{\beta_{t} \tau_{t} B_{t}+\frac{\alpha_{t}}{R} w_{t+1} \bar{L}_{t+1} \tau_{t+1}}{B_{t}\left(\tau_{t}+\frac{\alpha_{t}}{R} \bar{k}_{t} \frac{w_{t+1}}{w_{t}} \frac{\bar{L}_{t+1}}{\bar{L}_{t}} \tau_{t+1}\right)}
$$

Substituting for $\hat{\tau}_{t}$ and $\hat{\beta}_{t}$ shows that equation (16) is satisfied.

Next we prove that child pensions can be substituted by deductibility of child rearing costs.

Equation (14) and (16) change to

$$
\begin{aligned}
& B_{t}\left(1-\gamma_{t}\right)-\frac{\alpha_{t}}{R} w_{t+1} \bar{L}_{t+1} \tau_{t+1}=B_{t}\left(1-\hat{\gamma}_{t}\right) \\
& w_{t} L_{t}\left(1-\tau_{t}\right)+\gamma_{t} B_{t} k_{t}+\left[\left(1-\alpha_{t}\right) L_{t} \frac{\bar{k}_{t}}{\bar{L}_{t}}+\alpha_{t} k_{t}\right] \frac{\tau_{t+1} w_{t+1} \bar{L}_{t+1}}{R_{t+1}}-c_{t}-B_{t} k_{t} \\
& =w_{t} L_{t}\left(1-\hat{\tau}_{t}\right)+\hat{\gamma}_{t} B_{t} k_{t}+L_{t} \frac{\bar{k}_{t}}{\bar{L}_{t}} \frac{\tau_{t+1} w_{t+1} \bar{L}_{t+1}}{R_{t+1}}-c_{t}-B_{t} k_{t}
\end{aligned}
$$

while equation (15) is unchanged. Equation (14') gives

$$
\hat{\gamma}_{t}=\gamma_{t}+\frac{\alpha_{t}}{R} w_{t+1} \bar{L}_{t+1} \tau_{t+1}
$$

Thus, substituting $\hat{\tau}_{t}$ from (17) and $\hat{\gamma}_{t}$ shows that (16') is satisfied.

Q.E.D. 


\section{Insurance against infertility}

In literature it has been argued that public pension schemes can be viewed as an insurance against infertility (Sinn, 2004). If children are treated as investment goods yielding a pension in old age then couples who cannot have children can be insured against childlessness by receiving transfers from parents via a public pension scheme. Consumption in retirement is guaranteed by a redistribution from fertile to infertile couples. In the following we show that redistribution may go in the reverse direction from infertile to fertile individuals if the central planner's attitude towards inequality between types is neutral and utility is additive separable between consumption, leisure and child demand.

We extend the present model with a homogeneous population by assuming that an individual is ex ante infertile with probability $\theta$. In equilibrium, utility and budget constraint of a fertile individual are given by

$U_{1}\left(c_{t}^{F}\right)+U_{2}\left(k_{t}^{F}\right)+U_{3}\left(1-L_{t}^{F}\right)$

s.t. $w_{t} L_{t}^{F}\left(1-\tau_{t}\left(1-(1-\alpha) \bar{k}_{t} \frac{\tau_{t+1} w_{t+1} \bar{L}_{t+1}}{\tau_{t} w_{t} \bar{L}_{t} R_{t+1}}\right)\right)=c_{t}^{F}+\left(B_{t}-\alpha \frac{\tau_{t+1} w_{t+1} \bar{L}_{t+1}}{R_{t+1}}\right) k_{t}^{F}$

while an infertile individual obtains

$U_{1}\left(c_{t}^{I}\right)+U_{3}\left(1-L_{t}^{I}\right)$

s.t. $w_{t} L_{t}^{I}\left(1-\tau_{t}\left(1-(1-\alpha) \bar{k}_{t} \frac{\tau_{t+1} w_{t+1} \bar{L}_{t+1}}{\tau_{t} w_{t} \bar{L}_{t} R_{t+1}}\right)\right)=c_{t}^{I}$

Simplifying we denote $\tilde{\tau}_{t} \equiv \tau_{t}\left(1-(1-\alpha) \bar{k}_{t} \frac{\tau_{t+1} w_{t+1} \bar{L}_{t+1}}{\tau_{t} w_{t} \bar{L}_{t} R_{t+1}}\right)$ and $\tilde{B}_{t} \equiv B_{t}-\alpha \frac{\tau_{t+1} w_{t+1} \bar{L}_{t+1}}{R_{t+1}}$.

Let us consider different attitudes towards inequality of the central planner with respect to childlessness: neutrality and infinite aversion. In order to capture these attitudes in a generalized utility function we use the CES utility function with constant elasticity of substitution $\rho$ between the two life situations. A central planer taking account of aversion to inequality yields the first-best allocation by solving the following maximization problem:

$$
\begin{gathered}
\operatorname{Max}_{c, k, L}\left[(1-\theta)\left(U_{1}\left(c_{t}^{F}\right)+U_{2}\left(k_{t}^{F}\right)+U_{3}\left(1-L_{t}^{F}\right)\right)^{\rho}+\theta\left(U_{1}\left(c_{t}^{I}\right)+U_{3}\left(1-L_{t}^{I}\right)\right)^{\rho}\right]^{1 / \rho} \\
-\lambda\left\{(1-\theta)\left(c_{t}^{F}+\widetilde{B}_{t} k_{t}^{F}\right)+\theta c_{t}^{I}-\left(1-\tilde{\tau}_{t}\right) w_{t}\left((1-\theta) L_{t}^{F}+\theta L_{t}^{I}\right)\right\}
\end{gathered}
$$

If $\rho=1$ the central planner is neutral with respect to inequality and maximizes the Harsanyi welfare function. If $\rho \rightarrow-\infty$ the central planner is infinitely inequality averse and maximizes the Rawlsian maximin welfare function. 
In case of neutrality, the first-order conditions yield that - provided a strictly concave utility function - consumption and leisure have to be identical in both life situations in the first-best solution:

$U_{1}^{\prime}\left(c_{t}^{F^{*}}\right)=U_{1}^{\prime}\left(c_{t}^{I^{*}}\right) \Rightarrow c_{t}^{F^{*}}=c_{t}^{I^{*}}$

$U_{3}^{\prime}\left(1-L_{t}^{F^{*}}\right)=U_{3}^{\prime}\left(1-L_{t}^{I^{*}}\right) \Rightarrow L_{t}^{F^{*}}=L_{t}^{I^{*}}$

The first-order condition for the fertile with respect to children is

$U^{\prime}{ }_{2}\left(k_{t}^{F^{*}}\right)-\lambda \tilde{B}_{t}=0$

Note that this condition determines the number of children in the decentralized equilibrium. This first-best allocation can be achieved by an ex post redistribution from the infertile individual to the fertile individual.

The sequence of events is the following. Individuals are unaware of the fact whether they can have children or not. The central planer determines the tax/subsidy for the individuals who have any positive number of children and the tax/subsidy for the individuals who have no children. Then individuals discover whether they are fertile or infertile and - given the tax-subsidy scheme - they choose their consumption and labor supply and the number of children if fertile.

Proposition 5: If the central planner is neutral with respect to inequality between life situations the first-best allocation can be decentralized with a lump-sum subsidy $S=\theta \widetilde{B}_{t} k_{t}^{F^{*}}$ to the fertile individual and a lump-sum tax $T=(1-\theta) \widetilde{B}_{t} k_{t}^{F^{*}}$ collected from the infertile individual.

Proof: The budget constraint of the fertile individual changes to

$w_{t} L_{t}^{F}\left(1-\tilde{\tau}_{t}\right)=c_{t}^{F}+\tilde{B}_{t} k_{t}^{F}-\theta \tilde{B}_{t} k_{t}^{F *}$

while the budget constraint of the infertile individual changes to

$w_{t} L_{t}^{I}\left(1-\tilde{\tau}_{t}\right)=c_{t}^{I}+(1-\theta) \tilde{B}_{t} k_{t}^{F^{*}}$

The utility-maximizing fertile individual demands children according to $U^{\prime}{ }_{2}\left(k_{t}^{F}\right)-\lambda \widetilde{B}_{t}=0$. Thus, the first-best demand for children will be pursued: $k_{t}^{F}=k_{t}^{F^{*}}$. Furthermore, in both lifetime situations the individual will choose the same levels of consumption and leisure $c_{t}^{F}=c_{t}^{I}=c_{t}^{i *}, L_{t}^{F}=L_{t}^{I}=L_{t}^{i^{*}}, i=F, I$. The government budget is fulfilled: $(1-\theta) S=\theta T$.

Q.E.D. 
With neutrality towards inequality, all individuals whether fertile or not have the same weight in the social welfare function. Maximizing the Harsanyi welfare function means to equalize the marginal utility of consumption and leisure for both types of individuals. Due to their budget constraint parents with children have lower levels of consumption and leisure than infertile couples. This implies that their marginal utility is higher than that of infertile individuals. Equalizing marginal utilities then requires the redistribution of resources from infertile to fertile individuals.

If the central planner is completely averse towards inequality $(\rho \rightarrow-\infty)$ he maximizes

$$
\begin{gathered}
\underset{c, k, L}{\operatorname{Max}} \min \left[U_{1}\left(c_{t}^{F}\right)+U_{2}\left(k_{t}^{F}\right)+U_{3}\left(1-L_{t}^{F}\right), U_{1}\left(c_{t}^{I}\right)+U_{3}\left(1-L_{t}^{I}\right)\right] \\
\text { s.t. } \quad(1-\theta)\left(c_{t}^{F}+\widetilde{B}_{t} k_{t}^{F}\right)+\theta c_{t}^{I}=\left(1-\tilde{\tau}_{t}\right) w_{t}\left((1-\theta) L_{t}^{F}+\theta L_{t}^{I}\right)
\end{gathered}
$$

Proposition 6: At the first-best allocation of a central planner being completely averse towards inequality resources are redistributed from the fertile to the infertile individual.

\section{Proof:}

The central planer's maximization problem (22) can be written as:

$$
\underset{c_{t}^{F}, c_{t}^{I}, k_{t}^{F}, L_{t}^{F}, L_{t}^{I}}{\operatorname{Max}} U_{1}\left(c_{t}^{F}\right)+U_{2}\left(k_{t}^{F}\right)+U_{3}\left(1-L_{t}^{F}\right)
$$

s.t. (1) $U_{1}\left(c_{t}^{F}\right)+U_{2}\left(k_{t}^{F}\right)+U_{3}\left(1-L_{t}^{F}\right)=U_{1}\left(c_{t}^{I}\right)+U_{3}\left(1-L_{t}^{I}\right)$

$$
\text { (2) }(1-\theta)\left(c_{t}^{F}+\widetilde{B}_{t} k_{t}^{F}\right)+\theta c_{t}^{I}=\left(1-\tilde{\tau}_{t}\right) w_{t}\left((1-\theta) L_{t}^{F}+\theta L_{t}^{I}\right)
$$

The first-best solution is given by the following first-order conditions:

$$
\begin{aligned}
& \frac{U_{3}^{\prime}\left(1-L_{t}^{F}\right)}{U_{1}^{\prime}\left(c_{t}^{F}\right)}=\frac{U_{3}^{\prime}\left(1-L_{t}^{I}\right)}{U_{1}^{\prime}\left(c_{t}^{I}\right)} \\
& \frac{U_{2}^{\prime}\left(k_{t}^{F}\right)}{\widetilde{B}_{t}}=U_{1}^{\prime}\left(c_{t}^{F}\right) \\
& \left(1-\tilde{\tau}_{t}\right) w_{t} \frac{U_{2}^{\prime}\left(k_{t}^{F}\right)}{\widetilde{B}_{t}}=U_{3}^{\prime}\left(1-L_{t}^{F}\right)
\end{aligned}
$$

and the two constraints of (23). 
From the first constraint of (23) and (24) follows with $U_{2}\left(k_{t}^{F}\right)>0$ that

$c_{t}^{I}>c_{t}^{F} \quad$ and $\quad L_{t}^{I}<L_{t}^{F}$.

It is more costly for the infertile individual to finance her consumption and leisure level than it is for the fertile individual. Otherwise in achieving the same utility level the fertile individual would choose to have no children and the same consumption and leisure level as the infertile. Since both individuals have the same endowment this implies a redistribution from the fertile to the infertile individual at the first-best allocation.

Q.E.D.

In the case of complete inequality aversion, the Rawlsian welfare function assigns no weight to individuals with utility higher than the minimum. The optimal welfare is achieved with an equalization of utility levels. Since infertile individuals have a lower utility level than fertile resources have to be transferred to the infertile.

The difference in results for redistribution in both cases goes back to the weight given to individual types in both kinds of welfare functions. In the inequality neutral case all individual types have the same weight. Maximizing the aggregate utility sum means that redistribution has to go into the direction of the individuals with the higher marginal utility: to the fertile. In the case of complete inequality aversion only the utility level of the least favored counts. Thus resources have to redistributed to the individual type with the lowest utility level: the infertile.

\section{Conclusion}

In this paper we discuss the second-best implications of a pension type which is contingent on the individual numbers of children of a pensioner. In an overlapping generations model with endogenous fertility and labor supply we transform the government's decision problem of choosing the relevant pension parameters in a standard optimal-taxation problem with taxes on consumption and children. Our main results are the following.

A child pension should never completely replace a Bismarckian pension scheme in the most relevant case of children being more complementary to leisure than consumption goods. The reason is that the elimination of a Bismarck pension in favor of a child pension increases labor-leisure distortions by too much. Indeed, a mix of both pension types would balance the distortions of labor supply and fertility and produce a second-best optimum.

Alternative measures of family policy within the pension system - as the deduction of rearing costs from pension contributions - or outside the pension system - as child benefits - are equivalent instruments to set fertility incentives.

Finally, a fertility tax has a justification as an insurance against childlessness only if the government's attitude is sufficiently averse towards an unequal treatment of fertile and infertile individuals. If the central planner's attitude to inequality is neutral, the optimal 
redistribution goes from the childless to those with children, funded through a lump sum tax on the childless.

It should be noted that some features of child pensions have not been captured by our model and deserve further examination. Child pensions set financial incentives for fertility relatively late in an individual's life cycle. Thus, they are equivalent to other instruments of family policy which come to the aid of families earlier in life only if capital markets are perfect. If liquidity is especially tight for young families and future pensions cannot be perfectly advanced by capital markets policy instruments like child benefits or a rebate of pension contributions per child may be preferable to child pensions.

Furthermore, we have not analyzed the political credibility of pension reforms. The introduction of child pensions is a promise to help families in the far future after 30 years or so. This is a long time horizon susceptible to revoking policies of future governments. Other financial aids with immediate execution are more credible and, hence, allow to influence fertility more effectively. 


\section{References}

Aaron, H.J. (1966), “The Social Insurance Paradox”, Canadian Journal of Economics and Political Science 32, 371-374.

Atkinson, A.B. and N. Stern (1974), "Pigou, taxation and public goods”, Review of Economic Studies 41, 119-128.

Auer, L. von, and B. Büttner (2004), "Endogenous Fertility, Externalities, and Efficiency in Old Age Pension Systems", Journal of Institutional and Theoretical Economics, 160(2), 294-310.

Auerbach, A. (1985), “The theory of excess burden and optimal taxation”, in: Auerbach, A. and M. Feldstein (eds.), Handbook of Public Economics, vol. 1, 61-127.

Boadway, R. and P. Pestieau (2003), "Indirect taxation and redistribution: the scope of the Atkinson-Stiglitz theorem”, in: Kanbur, R. and R. Arnott (eds.), Imperfect Economics: Essays in Honor of Joseph Stiglitz, MIT Press.

Brunner, J. K. (1996), “ ”Transition from a Pay-As-You-Go to a Fully Funded Pension System: The Case of Differing Individuals and Intragenerational Fairness,” Journal of Public Economics 60, 131-46.

Corlett, W. and D. Hague (1953), "Complementarity and the excess burden of taxation", Review of Economic Studies 21, 21-30.

Edwards, J., M. Keen and M. Tuomala (1994), "Income Tax, Commodity Taxes and Public Good Provision: A Brief Guide”. Finanzarchiv 51, 472-97.

Fenge, R. (1995), "Pareto-efficiency of the pay-as-you-go pension system with intragenerational fairness”, Finanzarchiv 52, 357-364.

Fenge, R. and V. Meier (2004), “Are family allowances and fertility-related pensions perfect substitutes?”, CESifo Working Paper No. 1157.

Fenge, R. and V. Meier (2005), “Pensions and Fertility Incentives”, Canadian Journal of Economics 38, 28-48.

Goldman, S.M. and H. Uzawa (1964), “A Note on Separability in Demand Analysis”, Econometrica 32, 387-398.

Kolmar, M. (1997), "Intergenerational redistribution in a small open economy with endogenous fertility”, Journal of Population Economics 10, 335-356.

Nava, M., F. Schroyen and M. Marchand (1996), “Optimal Fiscal and Public Expenditure Policy in a Two-Class Economy”. Journal of Public Economics 61, 119-37. 
Sandmo, A. (1976), "Optimal taxation - An introduction to the literature", Journal of Public Economics 6, 37-54.

Sinn, H.-W. (2000), "Why a funded system is useful and why it is not useful", International Tax and Public Finance 7, 389-410.

Sinn, H.-W. (2004), "The pay-as-you-go pension system as fertility insurance and an enforcement device ”, Journal of Public Economics 88, 1335-1357. 


\section{CESifo Working Paper Series}

(for full list see www.cesifo-group.de)

1689 Gebhard Kirchgaessner and Silika Prohl, Sustainability of Swiss Fiscal Policy, March 2006

1690 A. Lans Bovenberg and Peter Birch Sørensen, Optimal Taxation and Social Insurance in a Lifetime Perspective, March 2006

1691 Moritz Schularick and Thomas M. Steger, Does Financial Integration Spur Economic Growth? New Evidence from the First Era of Financial Globalization, March 2006

1692 Burkhard Heer and Alfred Maussner, Business Cycle Dynamics of a New Keynesian Overlapping Generations Model with Progressive Income Taxation, March 2006

1693 Jarko Fidrmuc and Iikka Korhonen, Meta-Analysis of the Business Cycle Correlation between the Euro Area and the CEECs, March 2006

1694 Steffen Henzel and Timo Wollmershaeuser, The New Keynesian Phillips Curve and the Role of Expectations: Evidence from the Ifo World Economic Survey, March 2006

1695 Yin-Wong Cheung, An Empirical Model of Daily Highs and Lows, March 2006

1696 Scott Alan Carson, African-American and White Living Standards in the $19^{\text {th }}$ Century American South: A Biological Comparison, March 2006

1697 Helge Berger, Optimal Central Bank Design: Benchmarks for the ECB, March 2006

1698 Vjollca Sadiraj, Jan Tuinstra and Frans van Winden, On the Size of the Winning Set in the Presence of Interest Groups, April 2006

1699 Martin Gassebner, Michael Lamla and Jan-Egbert Sturm, Economic, Demographic and Political Determinants of Pollution Reassessed: A Sensitivity Analysis, April 2006

1700 Louis N. Christofides and Amy Chen Peng, Major Provisions of Labour Contracts and their Theoretical Coherence, April 2006

1701 Christian Groth, Karl-Josef Koch and Thomas M. Steger, Rethinking the Concept of Long-Run Economic Growth, April 2006

1702 Dirk Schindler and Guttorm Schjelderup, Company Tax Reform in Europe and its Effect on Collusive Behavior, April 2006

1703 Françoise Forges and Enrico Minelli, Afriat's Theorem for General Budget Sets, April 2006 
1704 M. Hashem Pesaran, Ron P. Smith, Takashi Yamagata and Liudmyla Hvozdyk, Pairwise Tests of Purchasing Power Parity Using Aggregate and Disaggregate Price Measures, April 2006

1705 Piero Gottardi and Felix Kubler, Social Security and Risk Sharing, April 2006

1706 Giacomo Corneo and Christina M. Fong, What's the Monetary Value of Distributive Justice?, April 2006

1707 Andreas Knabe, Ronnie Schoeb and Joachim Weimann, Marginal Employment Subsidization: A New Concept and a Reappraisal, April 2006

1708 Hans-Werner Sinn, The Pathological Export Boom and the Bazaar Effect - How to Solve the German Puzzle, April 2006

1709 Helge Berger and Stephan Danninger, The Employment Effects of Labor and Product Markets Deregulation and their Implications for Structural Reform, May 2006

1710 Michael Ehrmann and Marcel Fratzscher, Global Financial Transmission of Monetary Policy Shocks, May 2006

1711 Carsten Eckel and Hartmut Egger, Wage Bargaining and Multinational Firms in General Equilibrium, May 2006

1712 Mathias Hoffmann, Proprietary Income, Entrepreneurial Risk, and the Predictability of U.S. Stock Returns, May 2006

1713 Marc-Andreas Muendler and Sascha O. Becker, Margins of Multinational Labor Substitution, May 2006

1714 Surajeet Chakravarty and W. Bentley MacLeod, Construction Contracts (or "How to Get the Right Building at the Right Price?”), May 2006

1715 David Encaoua and Yassine Lefouili, Choosing Intellectual Protection: Imitation, Patent Strength and Licensing, May 2006

1716 Chris van Klaveren, Bernard van Praag and Henriette Maassen van den Brink, Empirical Estimation Results of a Collective Household Time Allocation Model, May 2006

1717 Paul De Grauwe and Agnieszka Markiewicz, Learning to Forecast the Exchange Rate: Two Competing Approaches, May 2006

1718 Sijbren Cnossen, Tobacco Taxation in the European Union, May 2006

1719 Marcel Gérard and Fernando Ruiz, Interjurisdictional Competition for Higher Education and Firms, May 2006

1720 Ronald McKinnon and Gunther Schnabl, China's Exchange Rate and International Adjustment in Wages, Prices, and Interest Rates: Japan Déjà Vu?, May 2006 
1721 Paolo M. Panteghini, The Capital Structure of Multinational Companies under Tax Competition, May 2006

1722 Johannes Becker, Clemens Fuest and Thomas Hemmelgarn, Corporate Tax Reform and Foreign Direct Investment in Germany - Evidence from Firm-Level Data, May 2006

1723 Christian Kleiber, Martin Sexauer and Klaus Waelde, Bequests, Taxation and the Distribution of Wealth in a General Equilibrium Model, May 2006

1724 Axel Dreher and Jan-Egbert Sturm, Do IMF and World Bank Influence Voting in the UN General Assembly?, May 2006

1725 Swapan K. Bhattacharya and Biswa N. Bhattacharyay, Prospects of Regional Cooperation in Trade, Investment and Finance in Asia: An Empirical Analysis on BIMSTEC Countries and Japan, May 2006

1726 Philippe Choné and Laurent Linnemer, Assessing Horizontal Mergers under Uncertain Efficiency Gains, May 2006

1727 Daniel Houser and Thomas Stratmann, Selling Favors in the Lab: Experiments on Campaign Finance Reform, May 2006

1728 E. Maarten Bosker, Steven Brakman, Harry Garretsen and Marc Schramm, A Century of Shocks: The Evolution of the German City Size Distribution 1925 - 1999, May 2006

1729 Clive Bell and Hans Gersbach, Growth and Enduring Epidemic Diseases, May 2006

1730 W. Bentley MacLeod, Reputations, Relationships and the Enforcement of Incomplete Contracts, May 2006

1731 Jan K. Brueckner and Ricardo Flores-Fillol, Airline Schedule Competition: ProductQuality Choice in a Duopoly Model, May 2006

1732 Kerstin Bernoth and Guntram B. Wolff, Fool the Markets? Creative Accounting, Fiscal Transparency and Sovereign Risk Premia, May 2006

1733 Emmanuelle Auriol and Pierre M. Picard, Government Outsourcing: Public Contracting with Private Monopoly, May 2006

1734 Guglielmo Maria Caporale and Luis A. Gil-Alana, Modelling Structural Breaks in the US, UK and Japanese Unemployment Rates, May 2006

1735 Emily J. Blanchard, Reevaluating the Role of Trade Agreements: Does Investment Globalization Make the WTO Obsolete?, May 2006

1736 Per Engström and Bertil Holmlund, Tax Evasion and Self-Employment in a High-Tax Country: Evidence from Sweden, May 2006

1737 Erkki Koskela and Mikko Puhakka, Cycles and Indeterminacy in Overlapping Generations Economies with Stone-Geary Preferences, May 2006 
1738 Saku Aura and Thomas Davidoff, Supply Constraints and Housing Prices, May 2006

1739 Balázs Égert and Ronald MacDonald, Monetary Transmission Mechanism in Transition Economies: Surveying the Surveyable, June 2006

1740 Ben J. Heijdra and Ward E. Romp, Ageing and Growth in the Small Open Economy, June 2006

1741 Robert Fenge and Volker Meier, Subsidies for Wages and Infrastructure: How to Restrain Undesired Immigration, June 2006

1742 Robert S. Chirinko and Debdulal Mallick, The Elasticity of Derived Demand, Factor Substitution and Product Demand: Corrections to Hicks' Formula and Marshall's Four Rules, June 2006

1743 Harry P. Bowen, Haris Munandar and Jean-Marie Viaene, Evidence and Implications of Zipf's Law for Integrated Economies, June 2006

1744 Markku Lanne and Helmut Luetkepohl, Identifying Monetary Policy Shocks via Changes in Volatility, June 2006

1745 Timo Trimborn, Karl-Josef Koch and Thomas M. Steger, Multi-Dimensional Transitional Dynamics: A Simple Numberical Procedure, June 2006

1746 Vivek H. Dehejia and Yiagadeesen Samy, Labor Standards and Economic Integration in the European Union: An Empirical Analysis, June 2006

1747 Carlo Altavilla and Paul De Grauwe, Forecasting and Combining Competing Models of Exchange Rate Determination, June 2006

1748 Olaf Posch and Klaus Waelde, Natural Volatility, Welfare and Taxation, June 2006

1749 Christian Holzner, Volker Meier and Martin Werding, Workfare, Monitoring, and Efficiency Wages, June 2006

1750 Steven Brakman, Harry Garretsen and Charles van Marrewijk, Agglomeration and Aid, June 2006

1751 Robert Fenge and Jakob von Weizsäcker, Mixing Bismarck and Child Pension Systems: An Optimum Taxation Approach, June 2006 